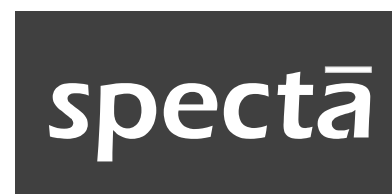

Journal of Photography, Arts, and Media

\section{KAJIAN ASPEK IDEASIONAL DAN INTERPRETASI BIOGRAFIS KARYA FOTO STEPHANUS SETIAWAN}

\author{
Bachtiar Firgiawan Wahono
}

Irwandi*

Kurniawan Adi Saputro**

Fakultas Seni Media Rekam, Institut Seni Indonesia Yogyakarta

Surel : insiyurwandi@yahoo.com

\begin{abstract}
Abstrak
Penelitian ini mengkaji aspek ideasional dan interpretasi biografis karya foto Stephanus Setiawan. Aspek ideasional adalah bagaimana seorang fotografer menyikapi fenomena alam dengan menemukan 'sesuatu' dan mengungkapkannya dalam berbagai bentuk konsep, teori, dan wacana. Adapun interpretasi biografis adalah cara untuk mencari jawaban sebab-akibat mengapa fotografer menghasilkan karya dengan ciri tertentu dengan mempertimbangkan latar belakang kepribadiannya. Dengan demikian bentuk tampilan sebuah foto sesungguhnya berkaitan dengan latar belakang kehidupan pembuatnya. Tujuan dari penelitian ini adalah untuk menjelaskan peranan proses kehidupan Stephanus Setiawan dalam perwujudan karya-karya fotonya. Penelitian ini menggunakan metode kualitatif dengan bentuk penyajian deskriptif atas fakta-fakta yang ditemukan. Setelah melalui proses observasi, wawancara dan penentuan sampel, karya-karya foto Stephanus Setiawan diteliti dengan pendekatan metode biografis. Pendekatan metode biografis berguna dalam menganalisis proses perkembangan Stephanus Setiawan untuk menemukan faktafakta yang memengaruhi proses penciptaan karya fotonya sehingga terlihat hubungan antara proses perkembangan karir Stephanus Setiawan dengan ide karya fotonya.
\end{abstract}

Kata kunci: aspek ideasional, interpretasi biografis, karya foto

\begin{abstract}
The Study of Ideational Aspects and Biographical Interpretation on Photographic Works by Stephanus Setiawan. This study examines the ideational aspect and biographical interpretation of the photographic works by Stephanus Setiawan. Ideational aspect is how a photographer deals with natural phenomena by finding 'something' and expresses it in various forms of concepts, theories, and discourses. The biographical interpretation is a way to find the answers of why photographers produce work with certain characteristics by considering the background of his own personality. Thereby, the look of a photograph actually relates to the background of the artist's life. The purpose of this research is to describe the role of Stephanus Setiawan's life processes in the manifestation of his photographic works. This research uses qualitative method with a descriptive presentation of the found facts. After the process of observation, interviews, and sampling, the photographic works of Stephanus Setiawan are analyzed with biographical approach method. This method is useful in analyzing the development process of Stephanus Setiawan to find facts that affect the process of creating his photographic works so as to make the relation of his development process in his career and his idea of photographic works visible.
\end{abstract}

Keywords: ideational aspects, biographical interpretation, photographic work

\footnotetext{
*Dosen di Program Studi Fotografi, Jurusan Fotografi, Fakultas Seni Media Rekam, ISI Yogyakarta

**Dosen di Pascasarjana ISI Yogyakarta
} 


\section{PENDAHULUAN}

Peran fotografi dari masa ke masa mengalami perubahan-perubahan. Lambat laun fotografi yang tadinya sekadar alat bantu menggambar, berangsur-angsur punya fungsi yang sama seperti halnya sebuah lukisan. Hal ini berkembang karena adanya kesadaran manusia sebagai makhluk yang berbudi/ berakal yang memiliki kemampuan lebih untuk dapat merekayasa alam lingkungan kehidupannya. Hal ini merupakan alasan yang kuat untuk memungkinkannya tetap bertahan dan menciptakan 'karya kehidupan' sebagai 'tanda' eksistensinya di dunia ini. Dalam konteks wacana fotografi adalah bagaimana seorang fotografer menyikapi fenomena alam dengan menemukan 'sesuatu' dan mengungkapkannya dalam berbagai bentuk konsep, teori, dan wacana (Soedjono, 2007: 8). Wacana fotografi dalam tataran ideasional ini juga merupakan pengimplementasian media fotografi sebagai wahana berkreasi dan menunjukkan ide serta jati diri seorang fotografer. Jati diri tersebut sangat erat kaitannya dengan riwayat hidup senimannya, maka dari itu muncullah pemahaman tentang interpretasi biografis. Adapun interpretasi biografis adalah cara untuk menemukan jawaban sebab-akibat mengapa fotografer menghasilkan karya dengan ciri tertentu dengan mempertimbangkan latar belakang kepribadiannya (Barrett, 2000: 47). Dengan demikian bentuk tampilan sebuah foto sesungguhnya berkaitan dengan latar belakang kehidupan pembuatnya. Ekspresi diri yang menciri dalam sebuah karya foto menjadi tujuan pencarian identitas pribadi seorang fotografer masa kini (Soedjono, 2007: 10).

Di Indonesia muncul banyak fotograferfotografer kreatif yang secara intens menciptakan karya fotografi. Salah satu komunitas fotografi yang sudah dikenal sejak lama adalah "Salon Foto". Dalam komunitas tersebut banyak fotografer-fotografer kelas nasional, bahkan internasional yang punya prestasi mentereng. Salah satu tokoh tersebut adalah Stephanus Setiawan.

Stephanus Setiawan adalah fotografer kelahiran Yogyakarta, 31 Maret 1952, yang punya segudang prestasi di kancah lomba foto nasional maupun internasional. Awal mula Setiawan terjun di bidang fotografi dimulai sejak dia berumur 12 tahun sebagai fotografer untuk liputan acara sekolah. Namun awal perjalanan sesungguhnya adalah pada tahun 1970, saat dia memutuskan untuk menjadi anggota HISFA Yogyakarta.

Sejak saat itu dia sangat rajin berpameran yang diawali dengan pameran fotografi di Solo yang diselenggarakan oleh FOCUS (Foto Club Surakarta) pada tahun 1971 dan Salon Foto Indonesia tahun 1973. Berawal dari itu, sejak tahun 1975 hingga sekarang berbagai lomba foto nasional hingga internasional selalu diikutinya. Selama itu dia telah memenangkan ratusan lomba foto hingga mendapatkan 21 gelar kehormatan dalam dunia fotografi.

Pada tahun 1980-1990 dia aktif dalam kegiatan Salon Foto/ Eksibisi foto yang dikoordinasi oleh FIAP (Federation Internationale de L'Art Photographique) yang berada di Belgia, dan merupakan salah satu kegiatan seni foto dunia di bawah naungan UNESCO, serta kegiatan foto yang dikoordinasi oleh PSA (Photographic Society of America) yang berpusat di Amerika Serikat.

Dari berbagai prestasi yang mentereng tersebut, dia mendapat kesempatan untuk menularkan ilmunya dengan menjadi staf pengajar di beberapa perguruan tinggi, antara lain di Fakultas Seni Media Rekam Institut Seni Indonesia Yogyakarta (1994-sekarang), Jurusan Komunikasi D-III Universitas Gadjah Mada, Akademi Komunikasi Indonesia Yogyakarta, serta Modern School of Design Yogyakarta. Khusus di FSMR ISI Yogyakarta, dia mengakui mulai merasakan adanya perubahan gaya foto 
yang mulai dipengaruhi kultur seni rupa dan mulai sejak itulah dia berpandangan bahwa fotografi juga bisa menjadi media berekspresi layaknya sebuah lukisan.

Dipilihnya Stephanus Setiawan sebagai subjek penelitian adalah karena pengaruh yang cukup kuat dalam dunia fotografi, khususnya di Indonesia. Dengan segala prestasi dan karya-karyanya, Setiawan layak untuk dijadikan subjek penelitian. Selain itu, secara pribadi, penulis yang juga lahir dan besar di Yogyakarta merasa perlu untuk mengetahui secara mendalam fotografer senior sarat prestasi yang masih berada dalam lingkup sekitar tempat tinggal penulis sebelum mengikuti perkembangan fotografi ke depannya. Terlebih lagi, Setiawan juga terbilang punya andil cukup besar atas berkembangnya Fakultas Seni Media Rekam ISI Yogyakarta, yang merupakan almamater dari penulis.

Dalam penelitian ini dipaparkan bahwa sebuah karya seni, dalam hal ini fotografi, sangat dipengaruhi oleh latar belakang pribadi seorang fotografer. Lebih jauh lagi diharapkan penelitian ini bisa berguna untuk menambah wawasan tentang pemahaman sebuah karya seni fotografi dan memahami sebuah potensi karya seni untuk bermetamorfosis dari sebuah ide menjadi sebuah mahakarya bernilai seni tinggi.

\section{Metode Biografis}

Laurie Schneider Adams dalam bukunya yang berjudul The Methodologies of Art: An Introduction (1996), menjelaskan metode biografis sebagai berikut ini:

"The biographical method of art history approaches works of art in relation to the artist's life and personality. It assumes a direct connection between artist and their art, and it takes seriously the notion of authorship. The meaning of a work, its conception and execution, is seen as ultimately determined by the artist, with social and economic factor playing in secondary role. (Adams, 1996: 60)..."

Dalam penelitian ini digunakan metode biografis untuk mencari aspek-aspek yang memungkinkan dijadikan sebagai landasan dalam menentukan sampelnya objek penelitian.

Franco Ferrarotti, dalam buku On the Science of Uncertainty: The Biographical Method in Social Research, menjelaskan beberapa hal mengenai batasan-batasan dalam metode biografis, antara lain:

1. Metode biografis menuntut untuk menghubungkan nilai pengetahuan pada subjektivitas.

Subjektivitas dari pencipta karya fotografi, dalam kasus ini Setiawan, adalah bahasan utama dalam penelitian ini. Sehingga melalui metode biografis ini berguna untuk mencari berbagai informasi yang bisa menjadi petunjuk-petunjuk tentang nilai subjektivitas dari seorang Setiawan yang dituangkan dalam sebuah karya foto.

2. Batasan metode biografis dibentuk berdasarkan spesifikasi materi biografis yang sudah dikelompokkan.

Dalam penentuan sampel objek penelitian sangat penting untuk memilah terlebih dahulu hal-hal apa saja yang bisa dijadikan dasar untuk mencari nilai subjektivitas dari Setiawan. Hal ini sangat erat kaitannya terhadap riwayat hidup Setiawan.

3. Batasan metode biografis juga diambil dari materi penting semacam prestasi, peristiwa, kasus, dan materi sejenis lainnya yang punya kaitan interpretasi lebih mengarah pada aspek ideasional.

Selain data diri Setiawan, prestasi atau peristiwa yang menjadi sorotan utama dalam hidup Setiawan, materi yang mengarah pada pandangan pribadi juga bisa dijadikan 
landasan dalam menentukan spesifikasi pemilahan sampel objek penelitian karena hal-hal tersebut juga erat kaitannya dengan proses berkarya seorang seniman.

Berdasarkan poin nomor 2 dan 3, batasan-batasan tersebut dibentuk berupa faktor-faktor yang mengacu pada bagan 2 , halaman 39 , tentang alur analisis data. Faktor-faktor tersebut memang sengaja dibuat sebagai bentuk batasan-batasan dari data yang didapat dengan memberikan kriteria khusus terhadap hal-hal yang dinilai mempunyai kesamaan sebagai poin-poin penting yang menunjukan bahwa faktorfaktor tersebut memiliki keterkaitan terhadap perwujudan karya foto Setiawan.

4. Subjektivitas dan tuntutan anti-nomotetis dari biografi menegaskan batas-batas keilmiahannya.

Dalam penelitian ini subjektivitas dari Setiawan menjadi pembeda dari kasus sejenis. Dalam artian, kemungkinan kasus yang sama akan ditemui juga pada seniman atau fotografer lain jika ditelusuri dengan metode biografis. Akan tetapi dalam dengan tuntutan untuk menemukan sesuatu yang khusus dalam sebuah penelitian, setiap kasus dari seniman tersebut bisa ditemukan sebuah kekhasan melalui subjektivitasnya masing-masing (Ferrarotti, 2003: 55-58).

\section{Teori Kritik Seni}

Edmund Burke Feldman dalam buku 'Varieties of Visual Experience: Fourth Edition' (1992) memperkenalkan tahapan teori kritik seni yang terbagi menjadi empat tahap, yaitu:

\section{Deskripsi}

Deskripsi adalah proses untuk menandai segala hal yang terlihat dalam sebuah karya secara kasat mata. Di tahap ini kita mencoba untuk menghindari hipotesis, penilaian, dan tanggapan personal. Intinya adalah, hanya membahas segala hal yang terlihat di karya tersebut. Dalam tahap deskripsi, bahasan yang mengarah ke suatu kritik sebisa mungkin dihindari; jadi dalam tahap ini tidak membicarakan sebuah nilai atau arti dari apa yang terlihat.

2. Analisis Formal

Dalam analisis formal, kita membahas lebih jauh tentang hal-hal yang telah dijabarkan dalam deskripsi untuk menemukan keterkaitan antara hal-hal yang sudah disebutkan dalam tahapan sebelumnya baik dari segi struktur bentuk, warna, tekstur, dll. dalam penampilan fisikal karya seni.

3. Interpretasi

Interpretasi dalam kritik seni sebuah proses untuk menemukan tafsiran secara menyeluruh dari sebuah karya yang telah dideskripsikan dan dianalisis pada tahapan sebelumnya terhadap keberadaan/ kehadiran karya seni. Ini bukan berarti dalam tahapan ini memberikan sebuah kesimpulan atau penilaian, karena sudah jelas, kita belum berada pada tahapan untuk memberikan penilaian sebuah karya sebelum kita tahu masalah apa yang sedang berusaha dipecahkan.

4. Penilaian

Penilaian merupakan upaya untuk menilai dan memberikan klasifikasi tertentu terhadap karya seni dengan membandingkannya dengan karya sejenis.Meskipun penilaian ini kadang bisa bersifat subjektif, namun tetap diupayakan agar tetap seobjektif mungkin (Feldman, 1992: 487-503).

\section{PEMBAHASAN}

\section{Pengharapan (2011)}

Foto ini (gambar 1) diambil di kawasan Tangkuban Perahu pada tahun 2011 bersamaan dengan acara hunting bersama jurusan fotografi FSMR ISI Yogyakarta. Di sana Setiawan memilih untuk jalan-jalan sendiri mencari 


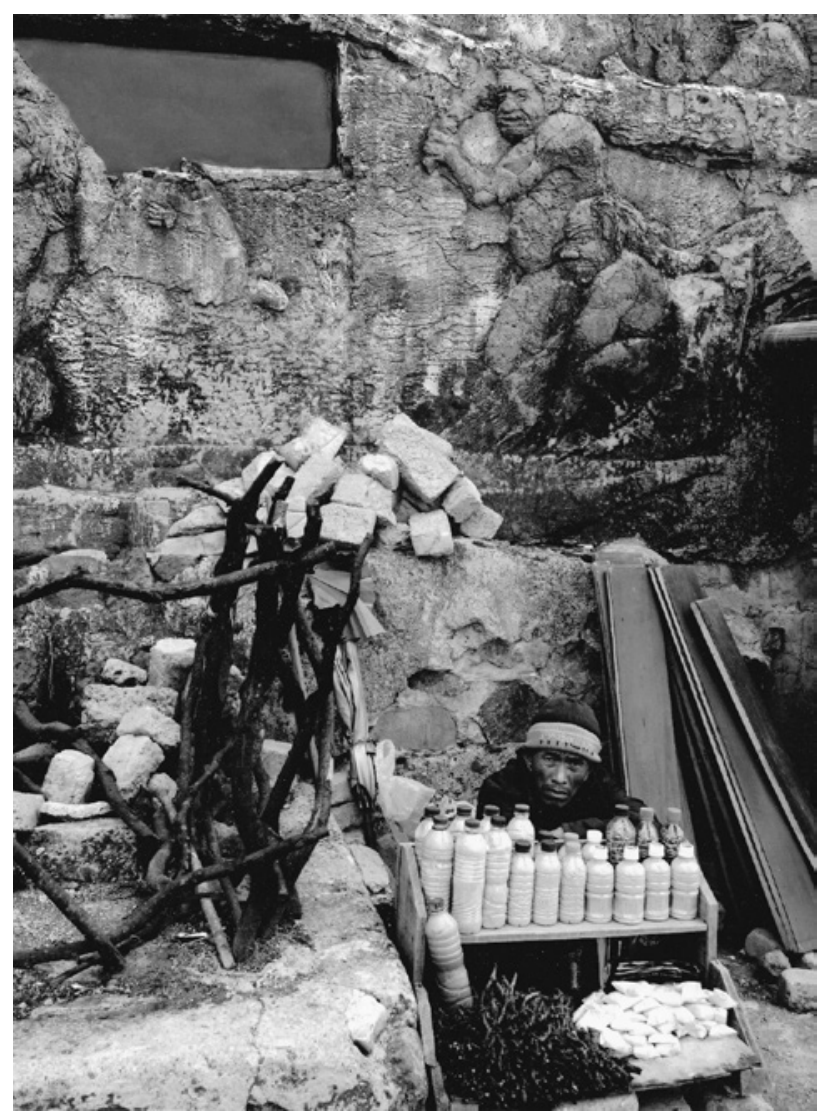

Gambar 1. "Pengharapan” karya Stephanus Setiawan (2011)

objek hingga akhirnya menemukan seorang pria yang menjajakan air kapur. Kamera yang digunakan oleh Setiawan juga sama, dengan kamera andalannya, Sony NEX-5n.

Setiawan mengabadikan pria yang menjajakan air kapur tersebut sedang termenung di sebuah pojokan menunggu datangnya pelanggan sambil memberikan ekspresi wajah muram melalui kameranya. Latar belakang dipenuhi bebatuan yang berserakan serta dinding semen yang masih kasar. Di dinding tersebut terdapat relief dengan figur sosok manusia yang sedang melakukan suatu pekerjaan. Subjek foto tampak mengenakan pakaian yang berguna untuk menghangatkan tubuhnya karena suhu udara yang dingin seperti jaket tebal dan kupluk. Bila dilihat dari segi penampilan wajah yang terkesan kusam, bisa dipastikan subjek foto merupakan seorang pria dari kalangan kaum pekerja.

Seperti biasanya, Setiawan mengemas karya fotonya ini secara sederhana. Sudut pengambilan gambar yang cenderung frontal, apalagi dengan ditampilkan secara hitamputih membuat pemirsa foto hanya terfokus pada elemen visual yang ada dalam foto ini. Hanya saja ada beberapa perbedaan visual yang terdapat dalam karya foto ini dibanding karya foto Setiawan kebanyakan. Pertama, pencahayaan utama dalam foto ini kurang begitu dominan. Setiawan yang biasa mengandalkan cahaya samping atau cahaya belakang dalam menciptakan karya foto, tidak dihadirkan dalam foto ini. Kedua, karya foto Setiawan yang biasanya sedikit elemen visual, kali ini dia tampilkan dengan cukup banyak elemen tambahan sebagai pelengkap subjek foto.

Segala hal mulai dari ekspresi wajah hingga latar belakang bebatuan yang keras dan kasar ini saling melengkapi dan memberikan interpretasi yang kuat tentang sebuah potret kehidupan yang keras. Ditampilkan secara hitam-putih, foto ini semakin memberikan kesan bahwa kehidupan orang ini tidak "berwarna". Penempatan subjek foto di bawahkanan bingkai juga seolah mempertegas kesan seseorang dalam keadaan sedang terhimpit secara konotatif maupun denotatif. Selain itu juga memberi makna bahwa subjek foto merupakan seseorang yang berada pada level strata sosial menengah ke bawah. Relief dengan figur manusia pada dinding semen meski tidak ada kaitannya dengan subjek foto bisa menjadi elemen visual pelengkap yang dimaknai bermacam-macam. Seolah-olah relief tersebut merupakan gambaran pikirannya yang dituntut harus selalu bekerja keras setiap hari, di sisi lain menggambarkan sosok figur yang menjadi atasannya yang selalu mengekang subjek foto dengan pekerjaan yang diberikannya.

Dalam karya ini, Setiawan memasukkan konten cerita, bahkan menyisipkan pesan tersebut secara semiotik yang dia pemahami setelah dia masuk FSMR ISI Yogyakarta. Raut wajah muram, duduk di pojokan, dengan latar belakang bebatuan yang tidak teratur dan 
tembok yang kasar, dikemas oleh Setiawan untuk merepresentasikan kehidupan yang keras dari subjek fotonya.

\section{Payung Fantasi (1988)}

Dari sekian banyak karya foto yang telah diciptakan oleh Setiawan, mungkin foto ini (lihat gambar 2) merupakan salah satu mahakaryanya, karena ini salah satu karyanya yang paling populer dan memang punya nilai visual yang istimewa.

Foto yang diambil di daerah Juwiring, Klaten, Jawa Tengah ini menampilkan seorang wanita paruh baya yang mengenakan pakaian tradisional sedang mengerjakan kerajinan payung kertasnya di sebuah ruangan yang masih berlantai tanah, berdinding batu bata serta pintu kayu tradisional. Di sekitar subjek foto terdapat payung-payung garapannya baik yang sudah jadi maupun setengah jadi serta kerangka payung dan benang yang menjadi bahan baku pembuatan payung. Di bagian

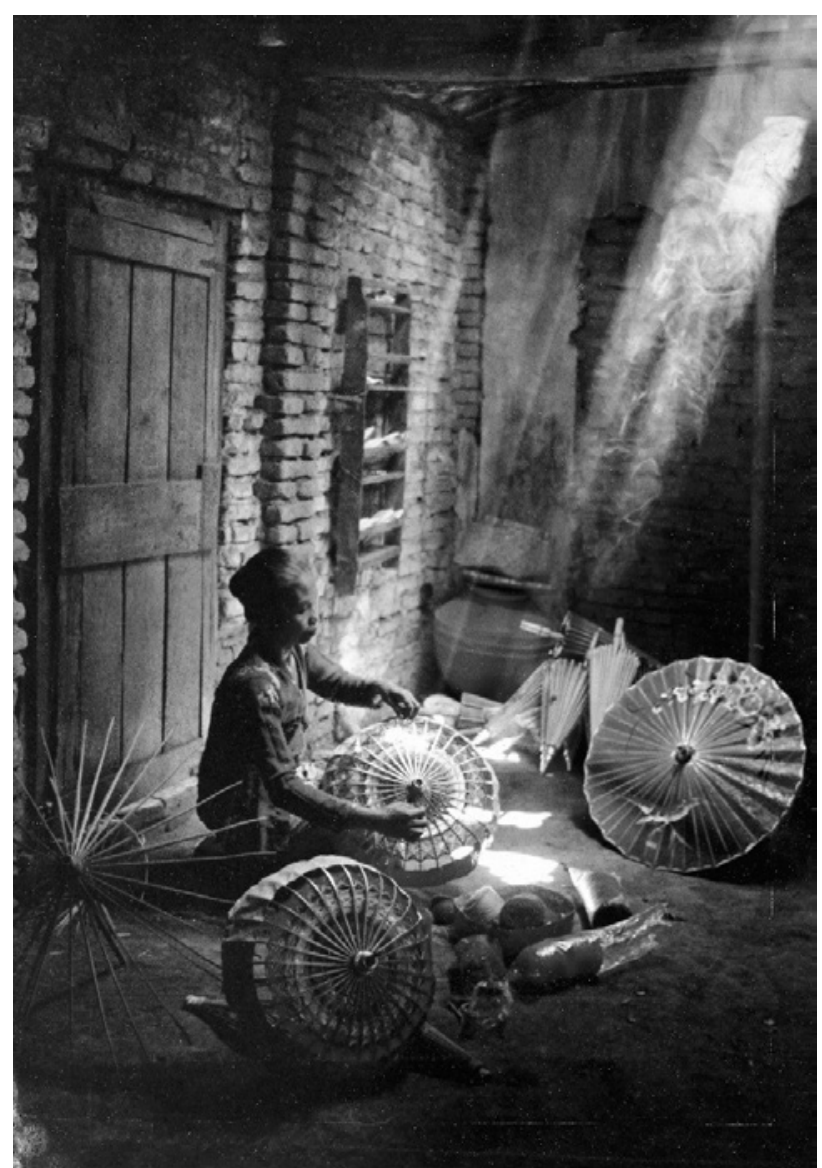

Gambar 2. "Payung fantasi” karya Stephanus Setiawan (1988) kanan atas bingkai terdapat cahaya terobosan yang diperkaya aksen asap.

Jika karya-karya lama sebelumnya Setiawan relatif sedikit memasukkan elemen visual, dalam karya ini menjadi perkecualian. Dengan sudut pengambilan gambar yang lebar, subjek utama foto yang sedang mengerjakan kerajinan payung mendapat banyak elemen visual pendukung mulai dari bahan baku pembuatan payung, payung yang belum jadi dan sudah jadi, lokasi pemotretan, hingga cahaya terobosan dan asap yang merupakan improvisasi dari Setiawan. Namun cahaya terobosan dalam foto ini bukan hanya berperan sebagai elemen tambahan. Cahaya dari atap yang punya intensitas cukup kuat ini mungkin tidak menguntungkan jika dijadikan sebagai pencahayaan utama, oleh karena itu cahaya ini dibiarkan jatuh ke lantai sehingga pancaran sinar yang jatuh pada subjek foto menjadi lebih halus dan justru menjadi cahaya samping. Tak lupa juga pakaian yang dikenakan oleh subjek foto juga menjadi elemen pendukung dalam foto ini.

Saat pertama kali melihat karya foto ini, satu hal yang pasti terlintas adalah kesan tradisional yang sangat kental. Pemilihan lokasi pemotretan dan pakaian yang dikenakan subjek menjadi petunjuk utama kesan tradisional ini. Adanya properti tambahan seperti payung baik yang sudah jadi maupun belum jadi serta bahan baku yang diletakkan di depan subjek foto memberi kesan kondisi produksi yang sebenarnya. Improvisasi yang ditambahkan oleh Setiawan berupa cahaya terobosan dan asap memberi kesan tersendiri yang menjadikan momen ini semakin syahdu. Terlepas dari kesan indah dan natural yang coba dibangun oleh Setiawan dalam foto ini, terselip juga ketidaklogisan yang ada dalam foto ini. Pintu kayu yang terkesan sangat klasik ini selain menjadi poin tambah juga bisa menjadi poin minus, karena pintu yang notabene merupakan jalur lalu lalang bagi 
orang yang tinggal di dalam rumah tersebut justru dihalangi oleh pengrajin yang sedang mengerjakan payung. Jika dipandang secara logika tentu saja ini menjadi hal yang aneh. Begitu juga dengan asap. Asap yang berasal dari damen yang dibakar oleh Setiawan khusus untuk memotret ini memang menambah kesan estetis karya foto, namun di sisi lain juga merupakan hal yang aneh karena payung kertas tidak mungkin dekat-dekat dengan api yang merupakan asal terjadinya asap.

Terlepas dari plus dan minusnya, foto ini tetaplah karya foto yang punya nilai estetis tinggi. Secara teknis foto ini direkam dengan pengukuran cahaya yang tepat, pencahayaan yang baik, dan pengkomposisian elemen visual yang tertata tanpa mengganggu subjek foto sebagai point of interest. Jika dilihat kontennya, dibanding 3 karya lama Setiawan sebelumnya, karya ini punya nilai kompleksitas paling tinggi dibanding yang lainnya. Ini berkat kondisi yang relatif bisa diatur oleh Setiawan sendiri. Jika karya lama sebelumnya berada di luar ruangan, foto ini berlokasi di dalam ruangan yang lebih mudah dikondisikan untuk pemotretan sehingga dalam karya ini Setiawan bisa menampilkan idenya supaya dapat berbicara lebih banyak.

\section{SIMPULAN}

Penelitian ini adalah upaya mencari hubungan antara karakter seorang seniman visual, atau dalam kasus ini adalah fotografer, mempunyai kaitan erat dengan karyanya berdasarkan proses perkembangan dalam karirnya yang kemudian memengaruhi aspek ideasional dari seniman tersebut yang pada akhirnya menjadi sebuah karakter yang khas dalam setiap karya-karyanya.Dari ulasan dua karya foto, bisa dipastikan bahwa faktor kebiasaan dan faktor pandangan pribadi Setiawan punya peran yang krusial terhadap perwujudan karya foto yang sudah dibuatnya.
Secara teknis, karya Setiawan mempunyai ciri yang cukup mempunyai kekhasan. Dalam karya-karya fotonya, Setiawan selalu memanfaatkan available light yang optimal untuk mendapatkan pencahayaan yang menghasilkan cahaya samping, cahaya belakang, hingga efek rim light. Setiawan hampir tidak pernah menggunakan perangkat lunak pengolah foto untuk mereka-reka pencahayaan karena baginya cara tersebut sudah melenceng dari prinsip fotografi. Karakternya yang selalu taat aturan tersebut juga diterapkannya dalam berbagai kondisi, misalnya hunting foto upacara keagamaan, pemotretan dengan garis horizon yang miring, juga selalu menekankan teknis yang benar. $\mathrm{Hal}$ tersebut merupakan dampak dari lingkungan keluarganya yang memiliki keturunan etnis Tionghoa yang dikenal memiliki etos kerja disiplin yang tinggi.

Dalam menciptakan karya foto, Setiawan sering melakukan riset terlebih dahulu terhadap kondisi lokasi dan pencahayaan sehingga dia dapat mengatur dengan lebih leluasa bagaimana proses pemotretan yang akan dia lakukan supaya bisa mendapat hasil foto yang optimal dan sesuai dengan ide yang ada dalam benaknya. Karakter ini terbentuk dari lingkungan Salon Foto yang selalu menekankan karya dengan keindahan semaksimal mungkin. Pola ini sudah mengakar dalam pikiran Setiawan, sehingga beberapa kondisi pemotretan yang sebenarnya lebih ke arah jurnalistik pun dia kerjakan dengan pola produksi selayaknya dia yang mengatur momen.

Karakter karya foto Setiawan yang mungkin jadi yang paling mencolok adalah kesederhanaan kontennya. Hal ini dipengaruhi beberapa hal yang cukup kompleks. Lingkungan belajarnya di Salon Foto membentuk pola pikir untuk selalu menciptakan karya yang sederhana, karena dengan kesederhanaan, ide yang ingin disampaikan oleh fotografer menjadi 
lebih mudah diterima pemirsa foto. Hal ini dikarenakan esensi dari Salon Foto merupakan sebuah lomba foto yang sistem penilaiannya adalah penjurian. Seorang juri lomba foto tidak akan punya cukup waktu untuk menilai satu per satu karya yang akan diseleksi menjadi pemenang Salon Foto, sehingga foto dengan konten sederhana namun punya karakter visual yang kuat punya peluang lebih tinggi untuk dipilih menjadi pemenang. Fakta ini membuat masyarakat yang mengikuti Salon Foto berusaha mengikuti fenomena ini demi bisa dipilih dewan juri menjadi pemenangnya. Secara otomatis, pola pikir fotografer Salon Foto juga dipengaruhi fakta ini dan Setiawan merupakan salah satunya. Hanya saja, secara pribadi Setiawan memang memiliki prinsip menjunjung nilai kesederhanaan dan rendah hati dari didikan orangtuanya. Setiawan yang lahir dan besar di Yogyakarta memiliki orientasi untuk menjalani hidup secara sederhana sedikit banyak juga merupakan dampak dari lingkungan tempat tinggalnya. Masyarakat Yogyakarta memang dikenal ramah, sederhana, dan rendah hati. Oleh karena itu, meski secara garis keturunan Setiawan memiliki darah etnis Tionghoa, namun sebagai orang asli Yogyakarta, Setiawan juga menjunjung tinggi nilai kebudayaan di Yogyakarta yang sarat nilai luhur. Percampuran dua budaya ini diakuinya berperan dalam membentuk kepribadiannya seperti sekarang ini.

Meski karya foto Setiawan mudah dikenali karena kesederhanaannya, seiring perkembangannya Setiawan mulai terlihat untuk lebih banyak memasukkan elemen visual di sekitar subjek foto secara lebih kompleks. Yang tadinya sekadar pelengkap visual, lambat laun menjadi pelengkap konten pesan yang ingin disampaikan oleh Setiawan. Perbedaan ini mulai terlihat dalam karya "Payung Fantasi" yang diakui Setiawan sudah berselang cukup lama setelah tahun-tahun awalnya belajar fotografi. Lalu perbedaan gaya tersebut semakin terlihat pada karyakaryanya setelah tahun 1994. Perbedaan ini diakuinya sebagai dampak dari lingkungan FSMR ISI Yogyakarta yang telah membuka cakrawala baru tentang penerapan ide dalam karya fotografi, sehingga sejak periode ini Setiawan memiliki perbedaan gaya di aspek pesan konten dalam karya fotonya.

Sedangkan karakter foto Setiawan jika dilihat dari aspek konten, bila ditarik dari seluruh karya foto yang dijadikan objek penelitian akan muncul benang merah bahwasanya karya foto Setiawan konsisten dengan nuansa kerohanian. Kerohanian dalam konteks karya foto Setiawan ini bukan mengenai agama atau kepercayaan tertentu, melainkan jiwa manusia secara universal.Dalam foto-fotonya Setiawan seringkali menggambarkan interaksi antara manusia dengan ruang di sekitarnya yang mengarah pada suasana kekhidmatan suatu momen dalam kehidupan. Kekhidmatan di sini sejatinya merupakan bahasa abstrak yang hanya bisa dirasakan dengan emosi dan intuisi.

Pada karya sebelum tahun 1994, yang notabene selama periode tersebut Setiawan kira-kira sedang berusia 20-an tahun hingga 40-an tahun, karya foto Setiawan cenderung mengedepankan aspek artistik. Nuansa kerohanian tersebut sudah tampak, hanya saja belum begitu terasa kental. Sedangkan karya-karya foto Setiawan setelah tahun 1994, di mana Setiawan mulai menuju usia kepala lima, nuansa kerohanian ini makin terasa kental yang dihadirkan dalam karya yang menjadi objek penelitian. Nuansa kerohanian ini sangat terasa bukan karena beberapa subjek fotonya merupakan potret momen upacara sakral. Dalam karya foto selain karya tersebut, nuansa kerohanian ini juga tetap terasa karena adanya sebuah gambaran interaksi antara manusia dengan ruang di sekitarnya.Jadi, jika dilihat dari faktor periode, bertambahnya usia juga punya andil dalam 
perwujudan karya Setiawan, bahwa semakin dewasa seseorang akan semakin peka tentang kebijaksanaan hidup yang berimbas pada nilai religiositas pribadi seseorang.

Bagi pemirsa foto yang pertama kali melihat konten foto Setiawan mungkin hanya sebatas takjub karena visual yang indah semata dan dengan segera melupakan sensasi tersebut karena konten yang sangat sederhana. Akan tetapi di balik kesederhanaan kontennya, karya foto Setiawan seakan selalu disertai semacam magnet visual jika kita perhatikan secara saksama yang kemudian membuat pemirsa foto terhenti pada suatu titik kekhidmatan dan membawa alam bawah sadar pemirsa foto merasakan momen pada karya foto Setiawan seolah berada di hadapan pemirsa. Sensasi tersebut bisa terasa karena adanya nuansa kerohanian yang disisipkan oleh Setiawan dalam karya-karya fotonya. Kelebihan tersebut yang Setiawan padukan dengan teknis pemotretan yang memukau telah menjadi nilai utama dalam karya-karya fotonya selama ini dan menjadi sebuah alasan kuat mengapa Setiawan meraih banyak supremasi serta menjaga eksistensinya di bidang fotografi hingga sekarang.

Hal tersebut membuktikan bahwa latar belakang biografis seorang fotografer punya andil besar terhadap terciptanya sebuah karya foto yang mana menjadi sebuah kekhasan dari masing-masing individu dalam menciptakan karyanya, seperti halnya seorang pelukis terhadap gaya dan konten lukisannya. Sebagaimana kata-kata Harry Callahan yang dikutip oleh Gene Markowski dalam buku "The Art of Photograph: Image and Illusion" (1984):

"The photographs that excite me are photographs that say something in a new manner; not for the sake of being different, but ones that are different because the individual is different and the individual expressed himself" (Markowski, 1984: 2).
Berkaca dari penelitian ini, bisa dikatakan ini masih sangat bisa dikembangkan lagi dengan topik yang lebih mendalam lagi. Dalam penelitian ini paling jauh membahas tentang sisi personal Setiawan dari aspek kebiasaan dan pandangan pribadinya. Dengan persiapan yang lebih matang, bukan tidak mungkin pembahasan sisi personal Setiawan bisa dikembangkan lagi menuju informasi yang lebih mendalam dari sumber-sumber yang dekat dengan Setiawan.

Penelitian ini bisa juga dijadikan sebagai acuan jika ada peneliti lain yang ingin membahas fotografer dalam negeri yang lain, baik itu melalui metode yang sama maupun dengan metode lain. Pada dasarnya, di Fakultas Seni Media Rekam masih sedikit tulisan-tulisan yang memuat tentang fotografer di Indonesia atau lebih spesifik lagi membahas tentang fotografer yang punya andil dalam membangun bersama FSMR ISI Yogyakarta, sehingga jika ada peneliti lain yang terdorong untuk melakukan penelitian tersebut, ini akan menjadi keuntungan bagi warga Fakultas Seni Media Rekam karena secara otomatis bagian dari sejarah fakultas dapat terdokumentasikan juga dan hal ini akan sangat membantu siapapun yang ingin mengetahui seluk beluk FSMR jika suatu saat nanti para pendiri FSMR sudah tidak bisa menjadi bagian dari fakultas ini lagi.

\section{KEPUSTAKAAN}

\section{Buku}

Adams, Laurie Schneider. The Methodologies of Art: An Introduction. Colorado: Westview Press. 1996.

Barrett, Terry. Criticizing Photographs: An Introduction to Understanding Images. Third Edition. New York: McGraw-Hill. 2000.

Feldman, Edmund Burke. Varieties of Visual Experience: Fourth Edition. Englewood Cliffs. New York: Harry N. Abrams, Inc. 1992. 
Ferrarotti, Franco. On the Science of Uncertainty: The Biographical Method in Social Research. United States of America: Lexington Books. 2003.

Markowski, Gene. The Art of Photography: Image and Illusion. New Jersey: Prentice-Hall Inc. 1984.

Soedjono, Soeprapto. Pot-Pourri Fotografi.

Jakarta: Penerbit Universitas

Trisakti. 2007. 